\title{
Epicarditis in a cat caused by feline infectious peritonitis virus: case report
}

[Epicardite em um gato causada pelo vírus da peritonite infecciosa felina: relato de caso]

\author{
G.A. Araujo ${ }^{1}$, E.C. Matta $^{1}$, M.A. Lallo ${ }^{1}$, G.F. Machado ${ }^{2}$, P.R.D. Rocha ${ }^{1 *}$ \\ ${ }^{1}$ Universidade Paulista - UNIP - São Paulo, SP \\ ${ }^{2}$ Universidade Estadual Paulista - UNESP - Araçatuba, SP
}

\begin{abstract}
Feline Infectious Peritonitis (FIP) is a progressive and fatal disease in domestic and wild cats, caused by Feline Infectious Peritonitis Virus (FIPV). The disease is characterized by an immunomediated reaction against the virus in various organs. This work described a case report of fibrinous epicarditis caused by FIPV. A male cat, three years old, died and was received to be necropsied. Grossly, soft, multifocal to coalescing, whitish fibrinous exudate, measuring up the 2 centimeters of thickness, was observed in the epicardium, mostly at the apex of the heart. Microscopically, severe, multifocal to coalescing inflammatory infiltrate was observed in the epicardium, composed mainly by macrophages, plasmocytes and lymphocytes, associated with fibrin deposition. Immunohistochemistry was performed for FIPV and was positive in the areas of inflammation in the epicardium. To the author's knowledge, this is the second report of epicarditis due to FIPV in a cat. Therefore, epicarditis should be considered a differential diagnosis of cardiac diseases in Feline Medicine.
\end{abstract}

Keywords: epicarditis, feline infectious peritonitis, immunohistochemistry, differential diagnosis

\section{RESUMO}

A Peritonite Infecciosa Felina (PIF) é uma doença progressiva e fatal de felinos domésticos e selvagens, causada pelo vírus da Peritonite Infecciosa Felina (FIPV). A doença é caracterizada por uma reação imunomediada contra o vírus em vários órgãos. Este trabalho descreveu um relato de caso de epicardite fibrinosa causada pelo FPIV. Um gato macho, com três anos de idade, veio a óbito e foi recebido para necropsia. Macroscopicamente, foi observado exsudato fibrinoso esbranquiçado, friável, multifocal, medindo até 2 centímetros de espessura, no epicárdio, principalmente no ápice cardíaco. Microscopicamente, foi observado no epicárdio um infiltrado inflamatório misto, multifocal, composto por macrófagos, plasmócitos e linfócitos, associado a deposição de fibrina. A imuno-histoquímica foi positiva para o FIPV nas áreas de inflamação no epicárdio. Os autores descrevem o segundo relato de caso na literatura científica de epicardite causada pelo FIPV em um gato. Portanto, a epicardite deve ser considerada como diagnóstico diferencial em doenças cardíacas em Medicina Felina.

Palavras-chave: epicardite, peritonite infecciosa felina, imuno-histoquímica, diagnóstico diferencial

\section{INTRODUCTION}

Feline Infectious Peritonitis (FIP) is a progressive and fatal disease in domestic and wild cats, so far without successful treatment (Tasker, 2018), caused by Feline Infectious Peritonitis Virus (FIPV), a single strand, positive sense, enveloped, RNA Coronavirus (Drechsler et al, 2011; Vermulen et al., 2013; Kipar and Meli, 2014; Pedersen, 2014). These viruses are capable of infecting various hosts due to their high recombination and mutations during replication, with varying virulence its main hosts, such as birds and mammals (Drechsler et al., 2011; Pedersen, 2014).

Recebido em 11 de março de 2019

Aceito em 24 de julho de 2019

*Autor para correspondência (corresponding author)

E-mail: ricardodellarmelina@gmail.com 
FIPV infection causes a systemic inflammatory process in cats, characterized by immunomediated lesions in almost all organs, such as the intestines, lungs, spleen, liver, kidneys, pancreas, lymph nodes, heart, brain and eyes (Drechsler et al, 2011; Kipar and Meli, 2014; Oliveira et al., 2014). In FIP, the anatomopathology is typically characterized by fibrinous and pyogranulomatous serositis, associated with pyogranulomas and high protein effusions in both abdominal and pleural cavities (Kipar and Meli, 2014). Microscopically, tissue lesions caused by the viral inflammation include granulomatous to pyogranulomatous perivascular inflammation and vasculitis, composed mainly by macrophages, lymphocytes, plasmocytes, and neutrophils (Drechsler et al., 2011).

In PIF, heart lesions, although rare, have already been described in the epicardium, characterized grossly and microscopically by fibrinous epicarditis (Oliveira et al., 2014). Moreover, pericardial effusion was also described in FIPV (Baek et al., 2017). The present case report described a case of epicarditis caused by FIPV by means of necropsy, histopathology and immunohistochesmistry for FIPV (IHC).

\section{CASE REPORT}

A male, mixed breed cat, castrated, three years old, died and was received at the Veterinary Teaching Hospital of Paulista University at São Paulo city, Brazil, for necropsy. Samples of the heart, lungs, liver, intestines, brain, spleen, kidneys and eyes were harvested and fixed at $10 \%$ buffered formalin solution for 48 hours, routinely processed for histopathology, and included in paraffin. Subsequently, $4 \mu \mathrm{m}$ tissue samples were cut in both glass and salinized slides for Hematoxylin and Eosin staining and IHC staining, respectively. This study was approved by the Animal's Ethics Committee of Paulista University ( $\left.\mathrm{N}^{\circ} 035 / 18\right)$.

IHC was performed from the spleen and the heart, as follows: briefly, slides were routinely deparaffinized with xylol; antigen retrieval was performed by citrate buffer at $\mathrm{pH} 6.0$ for 15 minutes at $100^{\circ} \mathrm{C}$. Subsequently, the endogenous peroxidase was blocked with peroxide hydrogen solution at $3 \%$ for 20 minutes. Then, primary monoclonal antibody (rabbit anti mouse Coronavirus (clone FIPV3-70, Thermo Fisher
Scientific, Sao Paulo, Brazil); was incubated overnight at $4^{\circ} \mathrm{C}$. Afterwards, the second antibody was applied (MP-7500, antimouse/rabbit IgG, Vector Labs). Subsequently, immunolabelling was revealed with diaminobenzidine (DAB, DAKO, California, USA) for 1 minute. Finally, slides were stained with Harris' Haematoxylin, washed and routinely mounted. All slides were analyzed under a light microscope at 4, 10, 20 and 400x magnifications.

Grossly, soft, multifocal to coalescing, whitish fibrinous exudate, measuring up the $2 \mathrm{~cm}$ of thickness was observed in the epicardium, mostly at the apex of the heart (Figure 1). Moreover, the liver was severely icteric, with multifocal nodules, resembling pyogranulomas, associated with fibrin deposition in the capsule (data not shown). Additionally, multifocal nodules were also observed in the spleen, lungs, and mesentery of the intestines (data not shown).

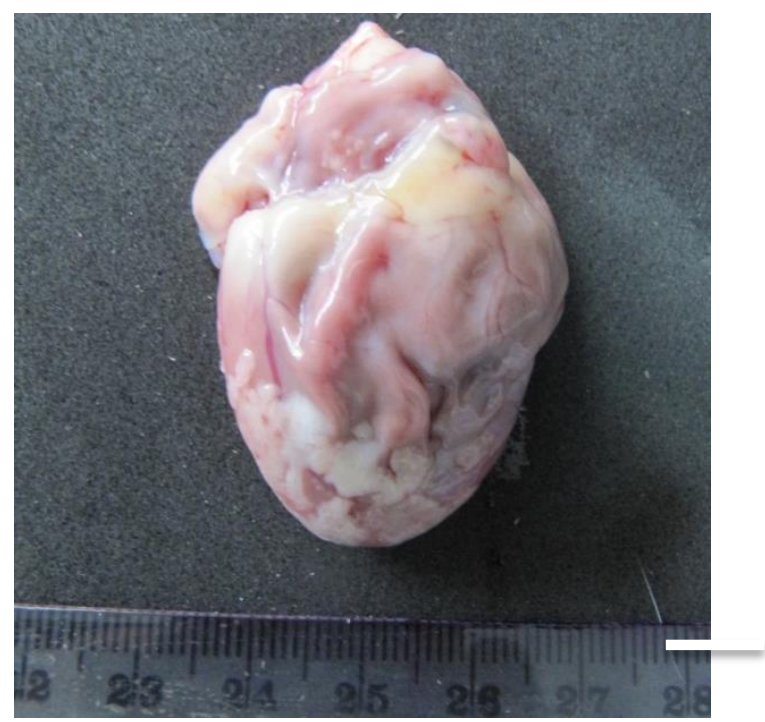

Figure 1. Heart. Multifocal fibrinous epicarditis. Multifocal, soft, whitish fibrinous exudate, with up to $2 \mathrm{~cm}$ in diameter, located mostly at the apex of the heart.

Microscopically, severe, multifocal to coalescing inflammatory infiltrate was observed in the epicardium, composed mainly by macrophages, plasmocytes and lymphocytes, and to a lesser extent, neutrophils, associated with fibrin deposition (Figure 2). Multifocal pyogranolomatous inflammation was also observed within the spleen, lungs, liver, and the serosa of the large intestine (data not shown). In 
the brain, multifocal granulomatous meningitis was also observed (data not shown). IHC immunolabelled FPIV in both spleen (data not shown) and heart (Figure 2C, D). FPIV immunolabelling was observed in the cytoplasm of cells resembling macrophages, as well as in the extracellular space adjacent to the pyogranulomatous inflammation.
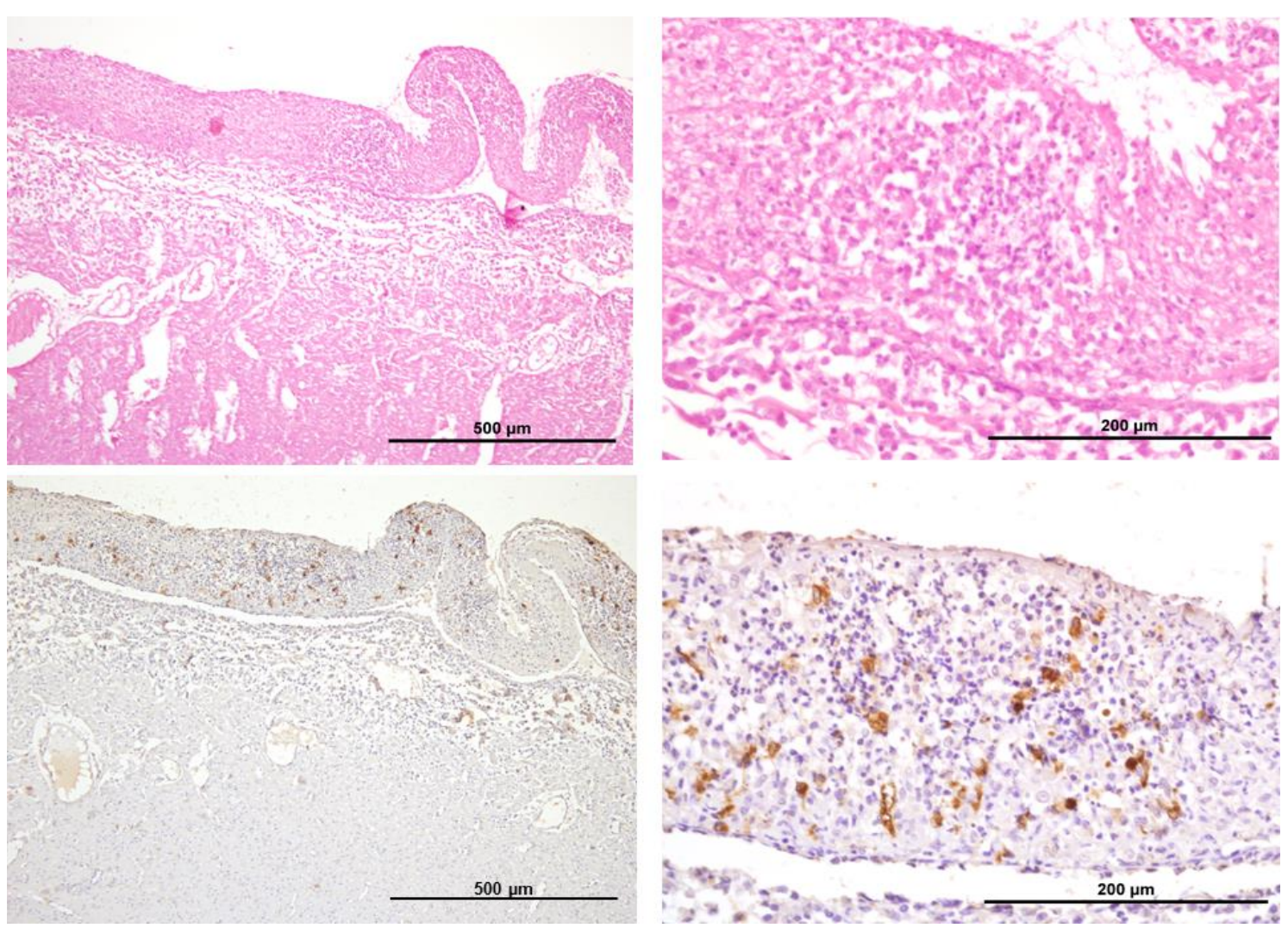

Figure 2. Heart. Epicarditis. A and B: Photomicrograph showing severe mixed epicarditis, composed mainly by macrophages, plasmocytes, lymphocytes and neutrophils, associated with fibrin deposition. Haematoxilin and Eosine staining. A 100x, B 400x. C and D: Multifocal immunolabelling for FPIV antigen within the cytoplasm of macrophages and within the extracellular space. Immunohistochemistry stained with DAB and Harris's Haematoxilin. C 100x, D 400x.

\section{DISCUSSION}

The postmortem diagnosis of FIP by anatomopathology is considered the gold standard for the etiological diagnosis. In fact, key factors are the typically observed gross and microscopic lesions associated with IHC positivity, which allows immunolabelling by the colocalization of FPIV within the lesions (Pedersen, 2014).

Epicarditis was already described as a consequence of FIPV infection only once in the literature, composed mainly by macrophages, neutrophils, plasmocytes and fewer lymphocytes (Oliveira et al., 2014). In the present case report, lesions were composed mainly by macrophages, plasmocytes and lymphocytes, with fewer neutrophils and fibrin deposition.

The multifocal/systemic inflammation caused by FIPV infection suggests that chemotaxis and immune cells migration occur due to the inflammatory process to limit FIPV spread throughout the body (Vermulen et al., 2013). Additionally, in FIP, viral infection increases pro-inflammatory factors, such as tumor necrosis factor alpha (TNF- $\alpha$ ) cytokine in infected macrophages and areas of inflammation, causing cell apoptosis. Overall, cats die due to a progressive, severe and deregulated activation of both innate and adaptive immune systems 
(Vermulen et al., 2013). Therefore, in the present case, epicarditis was most likely a consequence of viral spread throughout the cat's body in an attempt of the immune system to eliminate FIPV.

In Feline Medicine, heart lesions caused by infectious agents include: (i) FIPV (Tagawa et al., 2017); (ii) Feline Infectious Immunodeficiency Virus (FIV), as a cause of myocarditis (Rolim et al., 2015) in cats; (iii) Influenza A Virus strain $\mathrm{H} 5 \mathrm{~N} 1$, as a cause of myocardial necrosis associated with myocarditis (Rimmelzwaan et al., 2006) in cats; (iv) Bartonela henselae, which is also an important cause of myocarditis and endocarditis of the aortic valve in cats (Varanat et al., 2012); (v) and purulent pericarditis, caused by Klebsiella oxytoca in two lions (Kish et al., 2013). Moreover, even though previous studies suggested a role of Feline Panleukopenia Virus (FPV) as a cause of myocarditis in cats, more recent molecular biology studies showed no association of FPV with myocarditis in cats (Mcendaffer et al., 2017). Additionally, pericarditis is rare in cats, and is usually associated with bacterial septicemia (Tagawa et al., 2017). Furthermore, trauma, neoplasia, disseminated intravascular coagulation, and renal disease should also be included in the list of secondary causes of pericardial disease in cats (Tagawa et al., 2017).

In conclusion, to the best of the author's knowledge, this is the second case report of epicarditis due to FIPV in a cat. Since FIP is a progressive and fatal disease, epicarditis should be considered an important cause of heart diseases in Feline Medicine.

\section{REFERENCES}

BAEK, S.Y.; JO, J.G.; SONG, K.H.; SEO, K.W. Recurrent pericardial effusion with feline infectious peritonitis in a cat. J. Vet. Clin., v.34, p.437-440, 2017.

DRECHSLER, Y.; ALCARAZ, A.; BOSSONG, F.J.; COLLISSON, E.W. et al. Feline coronavirus in multi cat environments. Vet. Clin. N. Am. Small Anim. Pract., v.41, p.1133-1169, 2011.

KIPAR, A.; MELI, M.L. Feline infectious peritonitis; still an enigma? Vet. Pathol., v.51, p.505-526, 2014.
KISH， G.F.; KHODAKARAM-TAFTI, A.; TABRIZI, A.S.; SADOUGHIFAR, R. et al. Purulent pericarditis due to Klebsiella oxytoca in two lions: clinicopathological and microbiological findings. Comp. Clin. Pathol., v.22, p.1271-1274, 2013.

MCENDAFFER, L.; MOLESAN, A.; ERB, H.; KELLY, K. Feline panleukopenia virus is not associated with myocarditis or endomyocardial restrictive cardiomyopathy in cats. Vet. Pathol., v.54, p.669-675, 2017.

OLIVEIRA, L.B.; SUSTA, L.; RECH, R.R.; HOWERTH, E.W. Pathology in practice. effusive FIP with fibrinous epicarditis in a cat. $J$. Am. Vet. Med. Assoc., v.245, p.899-901, 2014.

PEDERSEN, N.C. An update on feline infectious peritonitis: diagnostics and therapeutics. Vet. J., v.201, p.133-141, 2014.

RIMMELZWAAN, G.F.; RIEL, D.V.; BAARS, M.; BESTEBROER, T.M. et al. Influenza a virus (H5N1) infection in cats causes systemic disease with potential novel routes of virus spread within and between hosts. Am. J. Pathol., v.168, p.176178, 2006.

ROLIM, M.V.; CASAGRANDE, R.A.; WOUTERS, A.T.; DRIEMEIER, D. et al. Myocarditis caused by feline immunodeficiency virus in five cats with hypertrophic cardiomyopathy. J. Comp. Path., v.154, p.3-8, 2015.

TAGAWA, M.; KURASHIMA, C.; SHIMBO, C.; OMURA, H. et al. Fibrinous pericarditis secondary to bacterial infection in a cat. J. Vet. Med. Sci., v.79, p.957-961, 2017.

TASKER, S. Diagnosis of feline infectious peritonitis. Update on evidence supporting available tests. J Feline Med Surg., v.20, p.228243, 2018.

VARANAT, M.; BROADHURST, J.; LINDER, K.E.; MAGGI, R.G. et al. Identification of Bartonella hanselae in 2 cats with pyogranulomatous myocarditis and diaphragmatic myositis. Vet. Pathol., v.49, p.608-611, 2012.

VERMULEN, B.L.; DREVIENDT, B.; OLYSLAEGERS, D.A.; DEDEURWAERDER A. et al. Suppression of NK cells and regulatory $\mathrm{T}$ lymphocytes in cats naturally infected with feline infectious peritonitis virus. Vet. Microbiol., v.164, p.46-59, 2013. 